done about space research? And oceanography? What is happening to the Southern Hemisphere Telescope, and will it ever be built? Is enough effort being devoted to biology? And does high-energy physics get too much ? It is a perennial puzzle that British scientists claim so small a voice in settling these and the host of other issues which touch directly on the conditions under which they work. It is true that there will often be plenty of grumbling after foolish decisions have been made and have become irrevocable through being invested with too much of the Government's prestige, but grumbling is no substitute for discussion. Rather, it amounts to acquiescence in the doctrine that governments should make decisions subject principally to the restraint that they may be called hard names if they consistently settle for outrageous policies.

All this will not, of course, be changed overnight, but there are a number of important steps which could be taken to broaden the base of public policy. The simplest. device of all would be the provision of more material with which to feed discussion. The Council for Scientific Policy has made a good start by undertaking and then publishing studies on matters such as the need of computers in universities, the recruitment and employment of undergraduates and the relationship between universities and government laboratories, but there is a great deal more that could be done. Why, for example, should not the council publish once a year the details of its recommendations to the Department of Education and Science on the prospective rate of growth of the research councils? Even if the minister or the Treasury should deny whatever claims are made, nobody need lose face and everybody would be wiser. Alternatively and perhaps more safely, the council and the other advisory committees could commission independent studies of particular questions- the now accelerator at CERN, for example -and then deliberately use published reports of these as means of testing professional opinion. This is a common and valuable procedure in North America. It will be remarkable if it has no part to play in Britain.

Other more adventurous innovations could easily bring greater benefits. One possibility, for example, would be to abandon the attempts of the research councils, particularly the Scicnce Research Council, to make research grants in accordance with some kind of consensus established by a hierarchy of committees, but instead to allow a short-term director freedom to make and pursue policies of his own. In, eircumstances like these, it would be much casicr than at present to do things for the first time. And for each advisory committce disbanded, there would be a thousand volunteer advisers determined to be heard. The result. might often be unseemly, but it might also be worth. while. And this, after all, is only one of the ways in which the administration of science might be made more simple, more efficient and more accessible al once to discussion and to understanding. It would be a public service if some advisory committce would give these questions a serious airing.

\section{WHAT NEXT AT HARWELL?}

Dr. ROBERT SPENCE is understandably proud of the achievements of the research establishment at which he is now director (see page 343). For much of the past 21 years, Harwell has played an influential part in British science well outside its strict terms of reference. In the years immediately after the Second World War, the then desolated airfield became a kind of Mecca for all kinds of people wishing to learn new techniques and to use equipment which the universities could not afford. The nuclear developments were important and attractive in themselves, of course, particularly when the rest of Britain was largely occupied with making good the dislocation caused by war, so that it is natural that Harwell should have gathered a splendid galaxy of talented people. But the establishment did what it could to give as well as to take, and its relationship with the universities has been friendly from the start. On many occasions it has served as a focus for academic work of various kinds, from cosmic rays to computers, seeking where it could to provide services on which the universities could call. The way the establiehment has spawned laboratories such as the Computer Laboratory at Chilton, now operated independently by the Science Research Council, is powerful evidence of the healthy influence of the cstablishment. Much of the credit for these developments belongs to the first director, Sir John Cockeroft, for liberal policies were by no means the natural ones to follow immediately after the war. Now, two decades later, it is only natural that Harwell should command the affections of a host of people.

But what of the next twenty-one years? It is unlikely that Dr. Spence's successors will have as simple a success story to tell. The trouble, of course, is that the establishment has outlasted the urgent, need that brought it into existence. It remains a centre of excellence, but there is at present no single task which can focus its energies in some natural direction. At the same time, unfortunately, the search for fresh objectives has by no means justified the hopes of those who thought, three years ago, that the establishment would be able to wave a magic wand over a large part of British industry. One difficulty is that the kind of research and development most urgently neccssary in British industry cannot easily be carried out at a distance. It remains to be scen whether the centres for research in ceramics and materials testing, like the research on water desalination, will have more bite, or whether some quite different project can give the establishment a new lease of life. Until and unless some goal emerges, the managers at Harwell must not be surprised if people elsewhere look enviously at the still considerable stock of skill which they have at their disposal. In the long run, the establishment may wcll be more valuable if it increases still further the considerable flow of people from Harwell to the outside world. To say this is not to suggest that it should close down, but rather that it should more openly seek to act as a leavening within industry. 